\title{
Tepidibacter formicigenes sp. nov., a novel spore-forming bacterium isolated from a Mid-Atlantic Ridge hydrothermal vent
}

\author{
Laurent Urios, Valérie Cueff, Patricia Pignet and Georges Barbier
}

Correspondence

Georges Barbier

georges.barbier@ifremer.fr
Laboratoire de Microbiologie et de Biotechnologie des Extrêmophiles, Département de Valorisation des Produits, IFREMER, Centre de Brest, BP 70, 29280 Plouzané, France

\begin{abstract}
A novel anaerobic, Gram-positive, sporulating and strictly chemoorganoheterotrophic bacterium, designated strain $\mathrm{DV} 1184^{\top}$, was isolated from a deep-sea hydrothermal vent sample from the Mid-Atlantic Ridge. The cells were short, straight rods ( $4 \mu \mathrm{m}$ long and $0.8 \mu \mathrm{m}$ wide) and were motile with peritrichous flagella. They grew between 35 and $55^{\circ} \mathrm{C}$ (optimum, $45^{\circ} \mathrm{C}$ ), between pH 5.0 and 8.0 (optimum, 6.0) and at 20-60 g sea salts $\mathrm{I}^{-1}$ (optimum sea salts concentration, $30 \mathrm{~g} \mathrm{I}^{-1}$ ). Strain DV $1184^{\top}$ was able to ferment yeast extract, tryptone, peptone, glucose, sucrose, maltose and pyruvate. The main fermentation products from glucose were (in decreasing order) formate, acetate and ethanol. The genomic DNA G +C content was 29 mol\%. Phylogenetic analysis of the $16 \mathrm{~S}$ rRNA gene located the strain within cluster XI of the lineage that encompasses the genus Clostridium and related genera in the bacterial domain. On the basis of $16 \mathrm{~S}$ rDNA sequence comparison and physiological and biochemical characteristics, it is proposed that the isolate should be described as a novel species, Tepidibacter formicigenes sp. nov. The type strain is DV $1184^{\top}\left(=\right.$ CIP $107893^{\top}=$ DSM $\left.15518^{\top}\right)$.
\end{abstract}

Among extreme environments, deep-sea hydrothermal vents contain large reservoirs of a wide variety of thermophilic and hyperthermophilic micro-organisms that belong to the Bacteria and Archaea. Micro-organisms from these environments use different metabolic ways to grow; they may be chemolithoautotrophs, chemoorganoheterotrophs or mixotrophs (Jeanthon, 2000). Several studies have demonstrated the presence of thermophilic bacterial aerobes (Marteinsson et al., 1995, 1996) and anaerobes (Antoine et al., 1997; Takai \& Horikoshi, 2000).

The order Clostridiales represents one of the largest bacterial groups, comprising a wide range of Gram-negative or -positive, psychrophilic to thermophilic, spore-forming or non-spore-forming, chemolithoautotrophic or chemoorganoheterotrophic strains that colonize various habitats. The presence of members of the order Clostridiales in hydrothermal vent environments was revealed by $16 \mathrm{~S}$ rDNA sequence analysis (Alain et al., 2002a; Wery et al., 2002). Anaerobic, heterotrophic thermophiles of the order Clostridiales have already been isolated from hydrothermal vents (Wery et al., 2001b; Alain et al., 2002b; Slobodkin et al., 2003). According to phylogenetic analysis based on $16 \mathrm{~S}$ rDNA sequences, 19 clusters were proposed within the genus Clostridium (Collins et al., 1994). Members of cluster XI exhibit a wide diversity of physiological and metabolic

The GenBank/EMBL/DDBJ accession number for the $16 \mathrm{~S}$ rDNA sequence of strain DV $1184^{\top}$ is AY 245527. characteristics; alkaliphiles (Li et al., 1993, 1994), halophiles (Fendrich et al., 1990) and thermophiles (Alain et al., 2002b) have already been described.

In this paper, we describe a moderately thermophilic, sporeforming bacterium that was collected from deep-sea vents located on the Mid-Atlantic Ridge and has phenotypic and phylogenetic characteristics that allow its assignment to a novel species within cluster XI of the order Clostridiales.

Samples were collected by the man-operated submersible DSV Nautile in 1994, during the DIVA2 cruise of deepsea vent fields of the Mid-Atlantic Ridge: Lucky Strike $\left(37^{\circ} 17^{\prime} \mathrm{N} 32^{\circ} 16^{\prime} \mathrm{W} ;-1600\right.$ to $\left.-1700 \mathrm{~m}\right)$ and MenezGwen $\left(37^{\circ} 51^{\prime} \mathrm{N} 31^{\circ} 31^{\prime} \mathrm{W} ;-800\right.$ to $\left.-1000 \mathrm{~m}\right)$. Titanium tubes that were half-filled with PEXS medium, solidified with Gelrite (Scott Laboratories) as a gelling agent, were placed near the plume of hydrothermal vents to allow circulation of hydrothermal fluid over the surface of the medium. PEXS medium was composed as follows: $0.5 \mathrm{~g}$ peptone $1^{-1}, 0.25 \mathrm{~g}$ yeast extract $\mathrm{l}^{-1}, 15 \mathrm{~g} \mathrm{NaCl} \mathrm{l}^{-1}$, $5 \cdot 0 \mathrm{~g}$ xylan $\mathrm{l}^{-1}$ and $15 \mathrm{~g}$ Gelrite $\mathrm{l}^{-1}$. PEXS medium was prepared with a salinity lower than that of sea water, as it was considered that this could be a characteristic of undiluted vent fluid. Each tube was collected by the DSV Nautile and placed in an insulated box filled with sterile sea water. The box was opened in an onboard laboratory under sterile conditions. Bottled tubes were shaken in an anaerobic chamber after addition of sterile sea water and 
glass beads. Subsamples were transferred to serum vials and cryotubes with $5 \%$ DMSO and were stored respectively at 4 and $-70{ }^{\circ} \mathrm{C}$.

Enrichment and isolation were performed by using PEXS medium that contained $30 \mathrm{~g}$ sea salts $\mathrm{l}^{-1}$ instead of $\mathrm{NaCl}$. Samples that were stored in serum vials and cryotubes were used for inoculation $(1 \%, \mathrm{v} / \mathrm{v})$ of PEXS medium at different temperatures $\left(50,65\right.$ and $\left.80{ }^{\circ} \mathrm{C}\right)$. Positive cultures were determined by microscopic observation and then purified. One isolate was designated strain DV1184 ${ }^{\mathrm{T}}$. Single colonies of this isolate were obtained by streaking on PEXS medium that was solidified with $15 \mathrm{~g}$ agar $\mathrm{l}^{-1}$. Plates were incubated in anaerobic jars for 3 days at $50{ }^{\circ} \mathrm{C}$. Colonies were subsequently picked and streaked twice under the same conditions. Microscope observation indicated that cells of isolate DV1 $184^{\mathrm{T}}$ were short, straight rods that exhibited tumbling motility during the exponential phase. The presence of flagella was investigated (Raguénès et al., 1997). Cells were stained negatively and transmission electron microscopy revealed the presence of peritrichous flagella, which explains the tumbling motility. Cells were approximately $4 \cdot 0 \pm 0 \cdot 2 \mu \mathrm{m}$ long and $0 \cdot 80 \pm 0 \cdot 05 \mu \mathrm{m}$ wide (mean value \pm $95 \%$ confidence interval) and appeared as single cells or in pairs. Under unfavourable growth conditions, cells elongated to form filamentous rods, as reported previously for other members of the order Clostridiales (Li et al., 1993; Alain et al., 2002b) (Fig. 1b). In the late-stationary phase of growth, cells formed an ovoid refractile subterminal endospore that was visible by phase-contrast microscopy (Fig. 1c). Ultrathin sectioning showed membrane-like structures surrounding the endospore (Fig. 1a). Cells stained Gram-positive by using a Gram Stain Set-S (Difco). Moreover, the Ryu KOH reaction (Powers, 1995) was negative, confirming the Gram-positive type of cells of strain DV1184 ${ }^{\mathrm{T}}$.

The new isolate was grown on glucose/yeast extract/ peptone/sea salts (GYPS) medium that contained $\left[(1)^{-1}\right]$ : $30 \mathrm{~g}$ sea salts (Sigma), $1 \mathrm{~g}$ bacto-peptone (Difco), $0.5 \mathrm{~g}$ yeast extract (Difco), 6.05 g PIPES buffer (Sigma), $5 \mathrm{~g}$ $\mathrm{D}-(+)$-glucose (Sigma) and $0 \cdot 1 \%(\mathrm{v} / \mathrm{v})$ resazurin solution. The $\mathrm{pH}$ was adjusted to $6 \cdot 0$ before autoclaving for $20 \mathrm{~min}$ at $121{ }^{\circ} \mathrm{C}$. The medium was reduced by addition of $0.5 \mathrm{~g}$ sodium sulfide before inoculation. Cultures were incubated at $45^{\circ} \mathrm{C}$ under anaerobic conditions at atmospheric pressure. Methods for the determination of growth parameters and enumeration of cells were reported previously (Wery et al., 2001b). Growth was observed at $35-55^{\circ} \mathrm{C}$ and the optimum temperature was around $45^{\circ} \mathrm{C}$. No growth was observed at 30 or $60^{\circ} \mathrm{C}$. The strain required $\mathrm{NaCl}$ for growth and grew at sea salt concentrations from 20 to $60 \mathrm{~g} \mathrm{l}^{-1}$ (corresponding to $15-46 \mathrm{~g} \mathrm{NaCl}^{-1}$ ). No growth was observed in the absence of sea salts or at a concentration of $80 \mathrm{~g}$ sea salts $\mathrm{l}^{-1}$. The optimum sea salt concentration was approximately $30 \mathrm{~g} \mathrm{l}^{-1}$ (corresponding to $23 \mathrm{~g}$ $\mathrm{NaCl} \mathrm{l}^{-1}$ ). Growth occurred at $\mathrm{pH} 5 \cdot 0-8 \cdot 0$; the optimum $\mathrm{pH}$ was around $6 \cdot 0$. In optimal conditions, the maximum cell concentration obtained was $10^{8}$ cells $\mathrm{ml}^{-1}$ and the shortest generation time observed was $16 \mathrm{~min}$.

Ability to use a single carbon source was investigated by adding one of the following compounds to GYPS medium (instead of glucose) to a final concentration of $0.5 \%$ $(\mathrm{w} / \mathrm{v})$ : D- $(+)$-sucrose, $\mathrm{D}-(+)$-glucose, $\mathrm{D}-(+)$-cellobiose, D- $(+)$-xylose, D- $(-)$-fructose, starch, cellulose, dextran, xylan, ethanol, pyruvate, succinate, lactate, maltose, D- $(+)$ mannose, D- $(+)$-trehalose, lactose, DL-arabinose, D- $(+)-$ galactose, D-(-)-ribose, L-(+)-rhamnose, D-mannitol, D-sorbitol, glycerol, peptone, tryptone, casein, albumin, gelatin, chitin, urea and olive oil. Strain DV1184 ${ }^{\mathrm{T}}$ was able to grow mainly on complex proteinaceous substrates and carbohydrates. Very weak growth was observed on yeast extract as the sole energy and carbon source. In the presence of $0.05 \%(\mathrm{w} / \mathrm{v})$ yeast extract, $\mathrm{D}-(+)$-glucose, pyruvate, sucrose, fructose and maltose supported growth

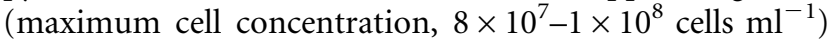
and poor growth was observed on ethanol, $\mathrm{D}-(+)$-mannose $\left(5 \times 10^{6}-6 \times 10^{6}{\left.\text { cells } \mathrm{ml}^{-1}\right)}^{-1}\right.$ and peptone $\left(2 \times 10^{7}\right.$ $2.5 \times 10^{7}$ cells $\mathrm{ml}^{-1}$ ), with regard to growth on a control medium that was made without substrates $\left(1 \times 10^{6}\right.$ $2 \times 10^{6}$ cells ml $\left.^{-1}\right)$. As ethanol-dependent growth is unusual, analysis of products was performed. The results showed an increase in acetate production of $21 \%$ $(2 \cdot 25 \mathrm{mM})$, with regard to the control medium without ethanol $(1.86 \mathrm{mM})$. None of the other organic acids,

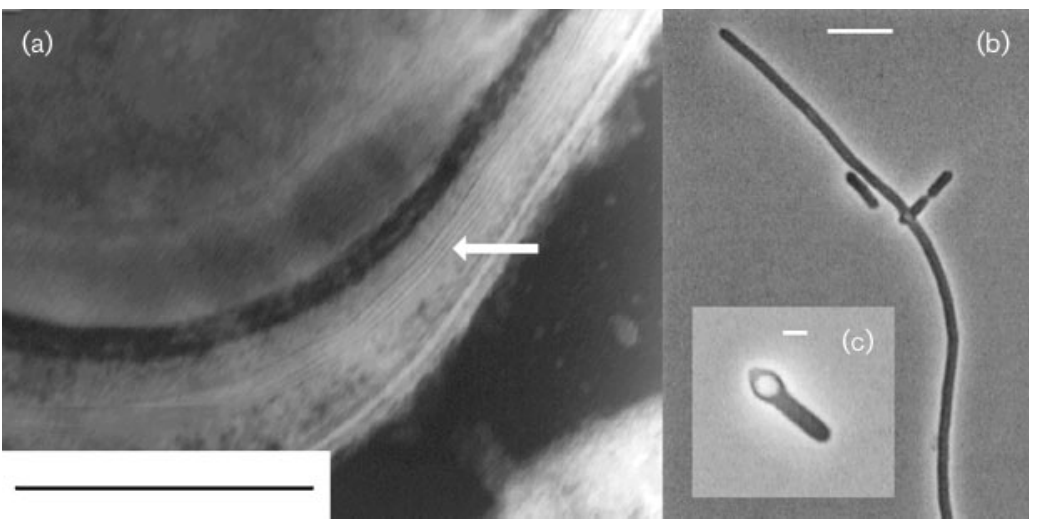

Fig. 1. Cell morphology of strain DV1184 grown in GYPS medium. (a) Ultrathin section of a sporulating cell. Arrow indicates membrane-like structures surrounding the endospore (bar, $0.5 \mu \mathrm{m}$ ). (b) Comparison between normal morphology and filamentous shape in non-optimal conditions (bar, $5 \mu \mathrm{m}$ ). (c) Sporulating cell in phase-contrast, showing a refractile subterminal endospore (bar, $1 \mu \mathrm{m})$. 
alcohols or carbohydrates that were tested in combination with $0.05 \%(\mathrm{w} / \mathrm{v})$ yeast extract supported growth (maximum cell concentration, $1 \times 10^{6}-2 \times 10^{6} \mathrm{cells}^{-1}$ ). Production of $\mathrm{H}_{2} \mathrm{~S}$ was investigated by using lead acetate paper, as indicated by Alain et al. (2002b). No significant production was observed with regard to the control. No requirement for an external electron acceptor was observed, as elemental sulfur $\left(10 \mathrm{~g} \mathrm{l}^{-1}\right)$, polysulfides (Blumentals et al., 1990), sodium thiosulfate (20 mM), sodium sulfite $(20 \mathrm{mM})$, sodium sulfate $(20 \mathrm{mM})$, sodium nitrite $(20 \mathrm{mM})$, sodium nitrate $(20 \mathrm{mM})$ and $\mathrm{FeCl}_{3}(10 \mathrm{mM})$ did not enhance growth.

Amino acids and organic acids as metabolic end products were analysed by means of HPLC, as described by Wery et al. (2001b). Products of glucose fermentation were acetate, ethanol and formate. After $24 \mathrm{~h}$ growth, final production per bacterial cell was $0.765 \mathrm{nmol}$ ethanol, $0.794 \mathrm{nmol}$ acetate and $1.29 \mathrm{nmol}$ formate. Production $\left(\mathrm{mol}\right.$ glucose used) ${ }^{-1}$ was about $1 \cdot 1 \mathrm{~mol}$ ethanol, $1.2 \mathrm{~mol}$ acetate and $1.9 \mathrm{~mol}$ formate. Production of formate was not reported for Clostridium paradoxum, Clostridium thermoalcaliphilum or Tepidibacter thalassicus, which were the most closely related micro-organisms. Such production has been reported for Caminicella sporogenes, but the concentrations obtained were 20-fold lower (Alain et al., $2002 b$ ). No production of lactate or succinate was observed. Thus, a modified mixed acid fermentation type for this organism is a hypothesis to be tested in the future. In such a case, lack of lactate and succinate production could lead to unusual production of the other compounds in this pathway, particularly formate.

During growth on GYPS medium, concentrations of serine, arginine, threonine and proline decreased quickly to zero during the early-exponential phase. A decrease in concentrations of isoleucine, methionine and leucine occurred during growth. Concentrations of tyrosine, valine, phenylalanine, aspartate, histidine and glutamate were reduced only during the stationary phase. An increase in concentrations of alanine and glycine was observed during the stationary phase. Such results have not been reported before.

Genomic DNA was extracted as described by Wery et al. (2001a), purified by $\mathrm{CsCl}$ gradient centrifugation (Wery et al., 2001b) and its $\mathrm{G}+\mathrm{C}$ content was determined by thermal denaturation, according to the method of Marmur \& Doty (1962) under the conditions reported by Raguénès et al. (1997). A calibration curve was obtained by using ultrapure DNA from Escherichia coli strain B $(\mathrm{G}+\mathrm{C}$ content, $50 \mathrm{~mol} \%)$, Clostridium perfringens $(26.5 \mathrm{~mol} \%)$ and calf thymus DNA (42 mol\%) as standards (Sigma). The genomic DNA G + C content of strain DV1184 ${ }^{\mathrm{T}}$ was $29 \mathrm{~mol} \%$. The $16 \mathrm{~S}$ rRNA gene was amplified selectively from purified genomic DNA by using the bacterial forward primer SAdir (5'-AGAGTTTGATCATGGCTCAGA-3'), which corresponds to positions 8-28 of the E. coli $16 \mathrm{~S}$ rRNA gene, and the bacterial reverse primer S17rev
(5'-GTTACCTTGTTACGACTT-3'), which corresponds to positions 1493-1509. The reaction was performed as described by Wery et al. (2001b). The PCR product was sequenced by using primers described by Raguénès et al. (1996). This work was done by Genome Express (France); $1380 \mathrm{nt}$ of the 16S rDNA sequence was determined. This sequence was then compared with others that were available in GenBank by using BLAST (Altschul et al., 1997). A multiple sequence file was obtained by using the MEGALIGN program of the DNASTAR package (Promega). Alignments and similarity levels were obtained by the CLUSTAL W method with weighted residues (Thompson et al., 1994). Alignments were corrected manually by using the multiple sequence alignment editor SEAVIEW and a phylogenetic tree was produced by using PHYLO_WIN (Galtier et al., 1996) with the following algorithms: Jukes-Cantor distance matrix and successively the neighbour-joining (Saitou \& Nei, 1987), maximum-parsimony and maximum-likelihood (Felsenstein, 1981) methods. Bootstraps values were determined according to Felsenstein (1985). Strain DV1184 was affiliated phylogenetically to the low- $\mathrm{G}+\mathrm{C}$ content, Gram-positive bacteria. The nearest relatives with validly published names were T. thalassicus, C. paradoxum and C. thermoalcaliphilum, with respective $16 \mathrm{~S}$ rDNA sequence similarity values of 95,93 and $93 \%$. According to these results, it was concluded that strain DV $1184^{\mathrm{T}}$ belonged to cluster XI of the lineage that encompasses the genus Clostridium and related genera. Cluster XI is very large and, consequently, the final phylogenetic reconstruction (Fig. 2) was performed only with closely related species among this cluster (with Caloranaerobacter azorensis as an outgroup).

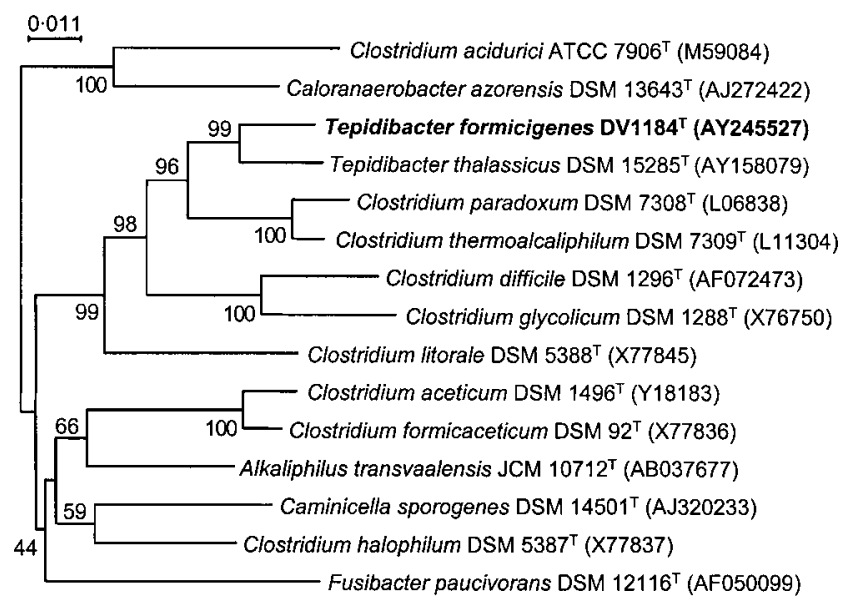

Fig. 2. Phylogenetic position of strain DV $1184^{\top}$ within cluster $\mathrm{XI}$ of the order Clostridiales. Caloranaerobacter azorensis and Clostridium acidurici were used as outgroups. GenBank accession numbers are noted in parentheses. The topology shown corresponds to an unrooted tree obtained by the neighbourjoining algorithm (Kimura correction) that was established by using PHYLO_WIN and refined manually by using SEAVIEW. Bootstrap values are displayed on their relative branches. Bar, 0.011 substitutions per nucleotide position. 
Pairwise evolutionary distances were computed by use of Kimura's two-parameter model (Kimura, 1980) and a dendrogram was constructed from these distances by use of the neighbour-joining method. The positioning of strain DV $1184^{\mathrm{T}}$ was supported by the results of the three phylogenetic algorithms that were used.

Strain DV1184 ${ }^{\mathrm{T}}$, a strictly heterotrophic and spore-forming bacterium that is able to ferment complex proteinaceous substrates and carbohydrates, has the major characteristics of the order Clostridiales. The lineage that encompasses the genus Clostridium and related genera is metabolically heterogeneous, containing a large proportion of fermentative and spore-forming micro-organisms (Rainey et al., 1993; Hippe et al., 1999; Takai et al., 2001). Similarities between T. thalassicus and strain DV1184 ${ }^{\mathrm{T}}$ include cell morphology, ability to form endospores and low genomic DNA G $+\mathrm{C}$ content. However, the position of the endospore was subterminal and not terminal, as has been shown for T. thalassicus. They also differ in geographical place of isolation, production of formic acid from glucose by strain DV1184 $4^{\mathrm{T}}$, efficient growth of strain DV1184 ${ }^{\mathrm{T}}$ on glucose, maltose, pyruvate, sucrose and fructose and weak growth on ethanol.

Based on phenotypic and genotypic differences and a $16 \mathrm{~S}$ rDNA dissimilarity value of $5 \%$ between strain DV1184 ${ }^{\mathrm{T}}$ and the nearest described species, we propose that strain DV $1184^{\mathrm{T}}$ should be assigned to a novel species of the recently described genus Tepidibacter in the order Clostridiales (Slobodkin et al., 2003). Due to its ability to produce formic acid, the name Tepidibacter formicigenes sp. nov. is proposed for this novel species.

\section{Description of Tepidibacter formicigenes sp. nov.}

Tepidibacter formicigenes (for.mi.ci.ge'nes. N.L. adj. formicicum from L. n. formica ant; Gr. v. gennaio produce; N.L. adj. formicigenes producing formic acid).

Rod-shaped, motile by means of peritrichous flagella, Gram-positive and endospore-forming bacteria. Growth occurs between 35 and $55^{\circ} \mathrm{C}$ (optimum, $45^{\circ} \mathrm{C}$ ), between pH $5 \cdot 0$ and $8 \cdot 0$ (optimum, $6 \cdot 0$ ) and at $20-60$ g sea salts $1^{-1}$ (optimum sea salts concentration, $30 \mathrm{~g} \mathrm{l}^{-1}$ ). Anaerobic, heterotrophic, able to ferment mainly proteinaceous substrates and carbohydrates. Produces ethanol, acetate and especially formate. Genomic DNA G $+\mathrm{C}$ content is 29 mol\%. The $16 \mathrm{~S}$ rRNA gene locates the strain within cluster XI of the lineage that encompasses the genus Clostridium and related genera in the bacterial domain, in the genus Tepidibacter. 16S rDNA similarity to Tepidibacter thalassicus is $95 \%$.

The type strain, DV1184 ${ }^{\mathrm{T}}\left(=\mathrm{CIP} 107893^{\mathrm{T}}=\mathrm{DSM} 15518^{\mathrm{T}}\right)$, was isolated from a sample collected on the Menez-Gwen hydrothermal site on the Mid-Atlantic Ridge $\left(37^{\circ} 51^{\prime} \mathrm{N}\right.$ $31^{\circ} 31^{\prime} \mathrm{W} ;-800$ to $-1000 \mathrm{~m}$ ).

\section{Acknowledgements}

We thank Daniel Desbruyères and Anne-Marie Alayse (IFREMER, Brest, France), chief scientists of the cruise DIVA2. We thank the captain and crew of N. O. Nadir and the DSV Nautile pilots and support crew. We thank Marie-Anne Cambon-Bonavita (IFREMER, Brest, France) for her support in phylogenetic analyses. We also thank Jean Sourimant (Station Biologique, Roscoff, France) for his technical support for transmission electron microscopy. This work was supported by IFREMER and the French Research Ministry (décision d'aide no. $00 \mathrm{G} 0178$ ).

\section{References}

Alain, K., Olagnon, M., Desbruyères, D., Pagé, A., Barbier, G., Juniper, S. K., Quérellou, J. \& Cambon-Bonavita, M.-A. (2002a). Phylogenetic characterization of the bacterial assemblage associated with mucous secretions of the hydrothermal vent polychaete Paralvinella palmiformis. FEMS Microbiol Ecol 42, 463-476.

Alain, K., Pignet, P., Zbinden, M. \& 8 other authors (2002b). Caminicella sporogenes gen. nov., sp. nov., a novel thermophilic spore-forming bacterium isolated from an East-Pacific Rise hydrothermal vent. Int J Syst Evol Microbiol 52, 1621-1628.

Altschul, S. F., Madden, T. L., Schäffer, A. A., Zhang, J., Zhang, Z., Miller, W. \& Lipman, D. J. (1997). Gapped BLAST and PSI-BLAST: a new generation of protein database search programs. Nucleic Acids Res 25, 3389-3402.

Antoine, E., Cilia, V., Meunier, J. R., Guezennec, J., Lesongeur, F. \& Barbier, G. (1997). Thermosipho melanesiensis sp. nov., a new thermophilic anaerobic bacterium belonging to the order Thermotogales, isolated from deep-sea hydrothermal vents in the southwestern Pacific Ocean. Int J Syst Bacteriol 47, 1118-1123.

Blumentals, I. I., Itoh, M., Olson, G. J. \& Kelly, R. M. (1990). Role of polysulfides in reduction of elemental sulfur by the hyperthermophilic archaebacterium Pyrococcus furiosus. Appl Environ Microbiol 56, 1255-1262.

Collins, M. D., Lawson, P. A., Willems, A., Cordoba, J. J., FernandezGarayzabal, J., Garcia, P., Cai, J., Hippe, H. \& Farrow, J. A. E. (1994). The phylogeny of the genus Clostridium: proposal of five new genera and eleven new species combinations. Int J Syst Bacteriol 44, 812-826.

Felsenstein, J. (1981). Evolutionary trees from DNA sequences: a maximum likelihood approach. J Mol Evol 17, 368-376.

Felsenstein, J. (1985). Confidence limits on phylogenies: an approach using the bootstrap. Evolution 39, 783-791.

Fendrich, C., Hippe, H. \& Gottschalk, G. (1990). Clostridium halophilium sp. nov. and C. litorale sp. nov., an obligate halophilic and a marine species degrading betaine in the Stickland reaction. Arch Microbiol 154, 127-132.

Galtier, N., Gouy, M. \& Gautier, C. (1996). SEAVIEW and PHYLO_WIN, two graphic tools for sequence alignment and molecular phylogeny. Comput Appl Biosci 12, 543-548.

Hippe, H., Hagelstein, A., Kramer, I., Swiderski, J. \& Stackebrandt, E. (1999). Phylogenetic analysis of Formivibrio citricus, Propionivibrio dicarboxylicus, Anaerobiospirillum thomasii, Succinimonas amylolytica and Succinivibrio dextrinosolvens and proposal of Succinivibrionaceae fam. nov. Int J Syst Bacteriol 49, 779-782.

Jeanthon, C. (2000). Molecular ecology of hydrothermal vent microbial communities. Antonie van Leeuwenhoek 77, 117-133.

Kimura, M. (1980). A simple method for estimating evolutionary rates of base substitutions through comparative studies of nucleotide sequences. J Mol Evol 16, 111-120. 
Li, Y., Mandelco, L. \& Wiegel, J. (1993). Isolation and characterization of a moderately thermophilic anaerobic alkaliphile, Clostridium paradoxum sp. nov. Int J Syst Bacteriol 43, 450-460.

Li, Y., Engle, M., Weiss, N., Mandelco, L. \& Wiegel, J. (1994). Clostridium thermoalcaliphilum sp. nov., an anaerobic and thermotolerant facultative alkaliphile. Int J Syst Bacteriol 44, 111-118.

Marmur, J. \& Doty, P. (1962). Determination of the base composition of deoxyribonucleic acid from its thermal denaturation temperature. J Mol Biol 5, 109-118.

Marteinsson, V. T., Birrien, J.-L., Kristjánsson, J. K. \& Prieur, D. (1995). First isolation of thermophilic aerobic non-sporulating heterotrophic bacteria from deep-sea hydrothermal vents. FEMS Microbiol Ecol 18, 163-174.

Marteinsson, V. T., Birrien, J.-L., Jeanthon, C. \& Prieur, D. (1996). Numerical taxonomic study of thermophilic Bacillus isolated from three geographically separated deep-sea hydrothermal vents. FEMS Microbiol Ecol 21, 255-266.

Powers, E. M. (1995). Efficacy of the Ryu nonstaining $\mathrm{KOH}$ technique for rapidly determining gram reactions of food-borne and waterborne bacteria and yeasts. Appl Environ Microbiol 61, 3756-3758.

Raguénès, G., Pignet, P., Gauthier, G., Peres, A., Christen, R., Rougeaux, H., Barbier, G. \& Guezennec, J. (1996). Description of a new polymer-secreting bacterium from a deep-sea hydrothermal vent, Alteromonas macleodii subsp. fijiensis, and preliminary characterization of the polymer. Appl Environ Microbiol 62, 67-73.

Raguénès, G., Christen, R., Guezennec, J., Pignet, P. \& Barbier, G. (1997). Vibrio diabolicus sp. nov., a new polysaccharide-secreting organism isolated from a deep-sea hydrothermal vent polychaete annelid, Alvinella pompejana. Int J Syst Bacteriol 47, 989-995.

Rainey, F. A., Ward, N. L., Morgan, H. W., Toalster, R. \& Stackebrandt, E. (1993). Phylogenetic analysis of anaerobic thermophilic bacteria: aid for their reclassification. J Bacteriol 175, $4772-4779$.
Saitou, N. \& Nei, M. (1987). The neighbor-joining method: a new method for reconstructing phylogenetic trees. Mol Biol Evol 4, 406-425.

Slobodkin, A. I., Tourova, T. P., Kostrikina, N. A., Chernyh, N. A., Bonch-Osmolovskaya, E. A., Jeanthon, C. \& Jones, B. E. (2003). Tepidibacter thalassicus gen. nov., sp. nov., a novel moderately thermophilic, anaerobic, fermentative bacterium from a deep-sea hydrothermal vent. Int J Syst Evol Microbiol 53, 1131-1134.

Takai, K. \& Horikoshi, K. (2000). Thermosipho japonicus sp. nov., an extremely thermophilic bacterium isolated from a deep-sea hydrothermal vent in Japan. Extremophiles 4, 9-17.

Takai, K., Moser, D. P., Onstott, T. C., Spoelstra, N., Pfiffner, S. M., Dohnalkova, A. \& Fredrickson, J. K. (2001). Alkaliphilus transvaalensis gen. nov., sp. nov., an extremely alkaliphilic bacterium isolated from a deep South African gold mine. Int J Syst Evol Microbiol 51, $1245-1256$.

Thompson, J. D., Higgins, D. G. \& Gibson, T. J. (1994). CLUSTAL W: improving the sensitivity of progressive multiple sequence alignment through sequence weighting, position-specific gap penalties and weight matrix choice. Nucleic Acids Res 22, 4673-4680.

Wery, N., Lesongeur, F., Pignet, P., Derennes, V., Cambon-Bonavita, M.-A., Godfroy, A. \& Barbier, G. (2001a). Marinitoga camini gen. nov., sp. nov., a rod-shaped bacterium belonging to the order Thermotogales, isolated from a deep-sea hydrothermal vent. Int J Syst Evol Microbiol 51, 495-504.

Wery, N., Moricet, J.-M., Cueff, V., Jean, J., Pignet, P., Lesongeur, F., Cambon-Bonavita, M.-A. \& Barbier, G. (2001b). Caloranaerobacter azorensis gen. nov., sp. nov., an anaerobic thermophilic bacterium isolated from a deep-sea hydrothermal vent. Int J Syst Evol Microbiol 51, 1789-1796.

Wery, N., Cambon-Bonavita, M.-A., Lesongeur, F. \& Barbier, G. (2002). Diversity of anaerobic heterotrophic thermophiles isolated from deep-sea hydrothermal vents of the Mid-Atlantic Ridge. FEMS Microbiol Ecol 41, 105-114. 